\title{
Pengolahan Bahan Pangan Rumah Tangga Untuk Mengurangi Intensitas Interaksi di Pasar Menuju New Normal Masa Pandemi Covid-19
}

\author{
Sulastri ${ }^{i^{*}}$, Yulia Hamdaini Putri ${ }^{1}$ dan Fida Muthia ${ }^{1}$ \\ ${ }^{1}$ Fakultas Ekonomi, Universitas Sriwijaya, Sumatera Selatan, Indonesia \\ *Email korespondensi: sulastri2310@gmail.com
}

Info Artikel: Diterima: 11 Januari 2021; Disetujui: 07 Juni 2021; Dipublikasi: 08 November 2021

\begin{abstract}
Abstrak: Selama Covid-19, masyarakat harus mengurangi intensitas berbelanja di pasar melalui penyediaan bahan makanan rumah tangga dalam jumlah yang lebih banyak untuk kebutuhan 2 sampai dengan 4 minggu. Untuk mempertahankan bahan makanan yang telah dibeli, dapat dilakukan pengolahan bahan makanan agar tetap memiliki cita rasa yang tinggi dan tahan lama. Mekanisme yang dapat dilakukan adalah dengan cara pelatihan dan tutorial pengolahan bahan makanan rumah tangga yang sering digunakan untuk dikonsumsi. Adapun tujuan dari dilakukannya kegiatan ini adalah sebagai berikut: 1) memberikan pelatihan praktis membuat olahan makanan yang tahan dan tetap memiliki cita rasa yang tinggi untuk memotivasi kahlayak sasaran membeli bahan dalam jumlah yang lebih banyak dengan cara stockist untuk persediaan 2 sampai 4 minggu, sebagai cara untuk mengurangi intensitas ke pasar tradisional, 2) memotivasi khalayak sasaran untuk mengurangi intensitas ke pasar tradisional dalam masa pandemi dan era new normal untuk memimalisir terjadinya transmisi Covid-19 pada klaster pasar tradisional. Metode yang digunakan adalah metode tutorial dan praktek. Hasil dari kegiatan ini adalah memotivasi peserta maupun penularan informasi kepada khalayak masyarakat agar dapat mengolah bahan baku tahan lama, sehingga tidak ada alasan untuk selalu sering pergi ke pasar untuk mendapatkan bahan baku kebutuhan sehari-hari. Dengan demikian akan terjadi pengurangan intensitas masyarakat ke pasar dalam rangka memitigasi transmisi Covid-19 dari klaster pasar tradisonal.
\end{abstract}

Kata Kunci: klaster covid19; pasar tradisional; intensitas; interaksi; pengolahan bahan pangan

\section{Kutipan:}

Sulastri, Putri, Y.H., \& Muthia, F. (2021). Pengolahan Bahan Pangan Rumah Tangga Untuk Mengurangi Intensitas Interaksi di Pasar Menuju New Normal Masa Pandemi Covid-19. Sricommerce: Journal of Sriwijaya Community Services, 2(2): 147-158. DOI: https://doi.org/10.29259/jscs.v2i2.52

\section{PENDAHULUAN}

Pandemi Covid-19 sebagai peristiwa menyebarnya penyakit korona virus 2019 yang terjadi di seluruh dunia. Terlepas dari faktor penyebabnya, bahwa pandemi ini telah berdampak luas terhadap berbagai sektor kehidupan. Kejadian ini pertama kali terdeteksi di Kota Wuhan, Provinsi Hubei, Tiongkok pada tanggal 1 Desember 2019, dan ditetapkan sebagai pandemi oleh Organisasi Kesehatan Dunia (WHO) pada tanggal 11 Maret 2020 termasuk negara Indonesia sebagai negara yang terdampak. Di Indonesia pandemi Covid-19 diumumkan oleh presiden Jokowi sejak tanggal awal Maret 2020. Setelah itu berbagai daerah mulai terlihat adanya kepanikan yang ditandai dengan berbagai aktivitas seperti local lockdown, Pembatasan Sosial Berskala Besar (PSBB) sebagai cara untuk melakukan physical distancing, pengurangan aktivitas keramaian, termasuk mengurangi interaksi langsung antar manusia. 
Salah satu interaksi langsung antar manusia yang paling sering dilakukan adalah interaksi jual beli baik pada pasar-pasar tradsional maupun pasar modern, dengan tujuan untuk memenuhi kebutuhan sehari-hari. Beberapa penelitian telah menunjukkan bahwa salah satu transmisi Covid19 terjadi pada pasar-pasar tradisional atau wet market (Yeongjun, James, 2020; Ivica Petrikova, Jennifer Cole, Andrew Farlow, 2020). Yeongjun, James (2020) telah menunjukkan bahwa penularan virus Covid-19 dari pasar ke manusia jauh lebih tinggi dan dengan dinamika yang sangat cepat dibandingkan dari manusia ke manusia. Sebagaimana juga dilansir dari Jakarta Post, "Indonesia wet markets carry high risk of virus transmission" (Jakarta Post/06/04, 2020). Kekhawatiran terhadap pasar tradisional sebagai area potensial transmisi Covid-19 ditunjukkan oleh beberapa kasus yang terkonfirmasi, terdapat 26 kasus baru di pasar Cileungsi Bogor, 20 kasus di Pasar Klender Jakrta Timur, dan 14 kasus di Pasar Serdang Jakarta Pusat. Di antara 12,3 juta pedagang di 13.450 pasar tradisional di seluruh Indonesia, asosiasi telah mencatat sebesar 535 pedagang di 20 provinsi tertular virus, 29 di antaranya telah meninggal dunia. Jumlah kasus tertinggi yaitu 133 kasus di daerah Jawa Timur, (https://www.kompas.com/). Namun di Indonesia belum sepenuhnya untuk melakukan shutdown pada pasar-pasar tradisonal, bahkan sampai saat ini pasar tetap ramai dikunjungi pembeli dan pedagang Berbeda dengan beberapa negara lainnya yang sebagian besar melakukan shutdown terhadap pasar tradisonal (Aguirre, A. A., Catherina, R., Frye, H., \& Shelley, L., 2020; Lynteris C, Fearnley L., 2020). Penelitan lainnya juga mendukung bahwa strategi isolasi mandiri (Adam J Kucharski et al., 2020) dan strategi social distancing (A.J. Jawad, 2020) akan mengurangi transmisi penularan virus. Di Indonesia juga menetapkan beberapa kebijakan penaganan Covid-19 antara lain (1) physical distancing, (2) wajib memakai masker saat berada di ruang publik atau di luar rumah, (3) isolasi dengan gejala dan isolasi (karantina) di Rumah Sakit jika ada tanda klinis yang butuh layanan definitif di Rumah Sakit (Media Center Penanganan Covid-19, 2020, https://covid19.go.id/). Dari beberapa uraian di atas penting menempatkan isu untuk mengurangi interaksi antar manusia pada tempat kerumunan terutama pada pasar-pasar tradisional untuk menimalisir terjadinya transmisi Covid-19 baik dari pasar ke manusia maupun dari manusi ke manusia.

Kota Palembang termasuk kota yang terkategori zona merah sekitar bulan Agustus 2020 hingga saat ini. Berikut data yang diambil dari website http://dinkes.sumselprov.go.id/ ditunjukkan pada gambar 1. Hingga bulan Agustus 2020 tercatat di Sumatera Selatan sudah sebanyak 3.909 orang terkonfirmasi terdampak coronavirus, terbanyak di kota Palembang (lihat gambar 1). Di Kota Palembang juga terdapat fenomena terjadinya transmisi Covid-19 pada beberapa pasar tradisional seperti diberitakan oleh harian Kompas tentang klaster pasar tradisional yang mencatat 33 pedagang dan warga postifit Covid-19, dan pasar Kebun Bunga.

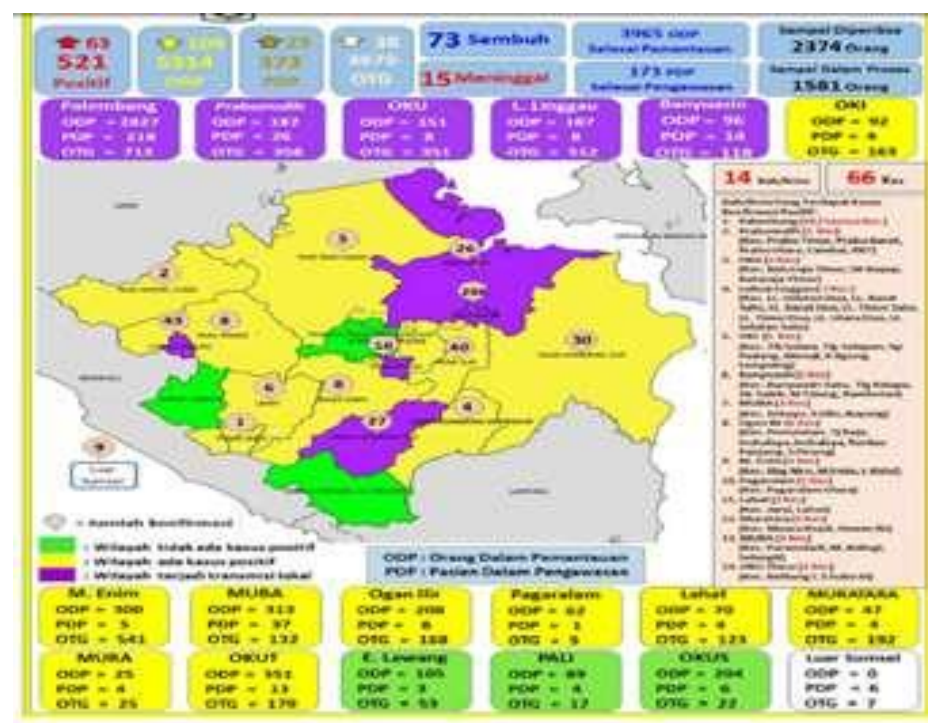

Gambar 1. Penyebaran Covid-19 di Sumatera Selatan (2020)

Demikian juga terjadi di beberapa pasar tradisional daerah lainnya seperti di Palangkaraya, 
sebanyak 46\% dari 226 kasus terkonfirmasi positif Covid-19 di ibu kota Kalimantan Tengah tersebut, dilaporkan berasal dari satu klaster yakni Pasar Besar. Lingkungan pasar ini menyumbang 102 kasus positif hingga Selasa 16 Juni 2020.

Di Jakarta, 64 pedagang pasar tradisional dinyatakan positif Covid-19, merujuk pada data yang dirilis IKAPPI pada Selasa (16/06). Berikut data 64 pedagang dari pasar tradisional di Jakarta yang terjangkit Covid-19: Pasar Kramat Jati: 3 orang, Pasar Perumnas Klender: 18 orang, Pasar Mester, Jatinegara: 1 orang, Pasar Serdang, Kemayoran: 23 orang, Pasar Kedip, Kebayoran Lama, 2 orang, Pasar Rawa Kerbau, 14 orang, Pasar Lontar: 1 orang, Pasar Obor, Cijantung 1 orang, Pasar Grogol: 1 orang. Dijakrta dapat dipastikan bahwa dua puluh empat pasar tradisional yang menjadi klaster penularan Covid-19 di DKI Jakarta kini ditutup, antara lain Pasar Kebayoran Lama, Pasar Lenteng Agung, Pasar Palmerah, Pasar Minggu dan Pasar Slipi (Ayomi Amindoni, 2020; Abdullah, 2020). Hal yang sama dinyatakan oleh Reynaldi Sarijowan Ketua Bidang Infokom Ikatan Pedagang Pasar Indonesia (IKAPPI) DPP (https://www.medcom.id/, Senin 9 Nov 2020 bahwa penyebaran virus korona di pasar tradisional masih mengkhawatirkan. Total ada 1.568 pedagang pasar tradisional yang positif terpapar Covid-19. Total kasus meninggal dunia sebesar 65 kasus. Kasus tersebut terdapat di 28 provinsi, 109 kabupaten/kota, dan terjadi di 275 pasar. Dari situasi ini dapat disimpulkan bahwa pasar tradisonal menjadi kluster transmisi Covid-19 yang sangat riskan.

Pengurangan intensitas interaksi di pasar dapat dilakukan dengan beberapa alternatif yang paling extreme adalah dengan cara shutdown dalam jangka waktu, namun hal ini banyak menuai pendapat yang kontradiktif, karena alasan ekonomi pedagang dan kebutuhan sehari-hari rumah tangga. Alternatif lainnya adalah dengan belanja online sebagaimana juga dilansir pada beberapa media bahwa digitalisasi cegah klaster Covid-19 pada pasar tradisional. Misalnya Grab melakukan inovasi digitalisasi belanja ke pasar dengan lebih dari 7000an titik pasar tradisional telah terdaftar dalam sistem pemetaan Grab, memungkinkan jutaan pelanggan Grab memesan kebutuhan harian dari jutaan pedagang tradisional dari rumah mereka dengan aman (https://kantorpemuda.com/). Pemerintah juga meluncurkan berbagai program digitalisasi pasar tradisonal pada masa pandemi untuk mengurangi interaksi langsung di pasar tradisional. Sejalan dengan Nur Indah Ariyani, Okta Hadi Nurcahyono (2014) yang menunjukkan bahwa digitalisasi pasar tradisonal merubah prilaku interaksi sosial masyarakat. Namun hal ini juga masih menemukan beberapa kelemahan, misalnya kebiasaan masyarakat pada pasar tradisional yang belum banyak mengenal sistem digital android, disamping itu tingkat pendidikan pedagang yang relatif rendah, serta lack time yang terjadi, membuat pedagang enggan menggunakan digitalisasi dibandingkan penjualan langsung. Walaupun telah banyak upaya yang dilakukan oleh pemerintah, swasta dan maupun masyarakat volunteer untuk mensosialisasikan program digitalisasi pasar tradisonal dalam masa pandemi, namun dari catatan yang dilansir pada media melaporkan bahwa tingkat penggunaan digitalisasi pasar tradisional pada masa pandemi hanya 10 persen di pasar Indonesia (https://ekonomi.bisnis.com/). Beberapa pendapat tentang digitalisasi pasar bahwa digitalisasi pasar tradisional sulit diimplementasikan karena literasi digital yang masih terbatas, pola pikir pedagang pasar yang tidak terbuka, serta minimnya fasilitas internet yang tersedia. Untuk daerah perkotaan, diperkirakan nilai transaksi hanya mencapai 25 persen dari total perputaran uang di pasar tradisional. Sementara itu, Ekonom Senior Institute for Development of Economic and Finance (INDEF) Enny Sri Hartati tak memungkiri jika skema digitalisasi pada pasar tradisional tidak bisa dilakukan dalam waktu relatif singkat. Proses digitalisasi pasar juga menjadi kendala bagi pengelola pasar, karena untuk melakukan digitalisasi retribusi tidak bisa langsung diterapkan, harus ada Peraturan Daerah.

Alternatif lainnya adalah dengan melakukan stockist yaitu penyediaan persediaan untuk jangka waktu tertentu untuk jangka waktu tertentu. Terlepas dari beberapa alternatif tersebut kegiatan pengabdian masyarakat yang ditawarkan adalah dengan cara melakukan pengaturan persediaan untuk bahan-bahan kebutuhan sehari-hari yang sering digunakan. Untuk selanjutnya bahan pangan tersebut diolah agar makanan tahan lama untuk waktu minimal dua sampai 4 minggu. Waktu ini dianggap sesuai untuk pengurangan intansitas ke pasar dalam masa transmisi Covid-19 dan atau jika terjadi shutdown pasar. Tentunya ada upaya untuk mensosialisasikan kepada masyarakat kapan akan dilakukan shutdown dan dalam waktu berapa lama, sehingga 
masyarakat dapat bersiap-siap untuk membeli kebutuhan bahan baku, bukan untuk menimbun bahan baku. Bahan baku ini perlu dipertahankan kualitasnya agar tahan lama dapat dikonsumsi serta mudah menyimpannya. Oleh karena itu, salah satu solusi untuk ini adalah dengan cara pengolahan bahan makanan tahan lama dan tetap sehat digunakan sebagai bahan pangan.

Bahan pangan yang sering digunakan yaitu dalam kehidupan sehari-hari selain bahan pokok beras dan gula, adalah cabai, bawang, dan tomat serta beberapa bumbu dapur seperti sereh, jahe dan minyak goreng. Bahan baku ini yang akan digunakan untuk diolah dengan beberapa produk jadi yang siap untuk dikonsumsi. Kegiatan ini juga rangkaian kegiatan yang telah dilakukan sebelumnya di Desa Kota Daro II (Sulastri et al., 2019). Cabai atau cabe merupakan salah satu jenis sayuran pelengkap dan bumbu masak yang diperlukan oleh hampir seluruh lapisan masyarakat Indonesia pada setiap saat. Cabai digemari oleh mayoritas masyarakat Sumatera Selatan khususnya Palembang yang suka dengan cita rasa pedas. Cabai termasuk salah satu bahan pangan yang mempunyai harga sangat berfluktuasi. Meskipun demikian, permintaan masyarakat terhadap cabai cenderung stabil. Cabai merah merupakan cabai yang paling sering dikonsumsi oleh rumah tangga dengan pangsa penggunannya mencapai $61 \%$ dari total konsumsi cabai dalam negeri (Dahlia, 2016). Cabai merah juga dimanfaatkan sebagai bahan baku industri dan ekspor baik dalam bentuk cabai segar maupun olahan, seperti, cabai kering dan cabai bubuk.

Selain cabai, tomat termasuk sayuran digemari masyarakat luas, sayuran yang dapat di budidaya. Pada aspek budidaya dapat dicampur dengan bahan atau zat tertentu baik tanaman maupun hewan (Arief, Fitriani, dan Subekti, 2014). Selain penggunaan zat, budidaya juga menggunakan teknik tertentu (Pugersari, Syarief, dan Larasati, 2013). Cabai dan tomat sangat cocok dijadikan pendamping makanan karena pangsa pasarnya di sukai remaja hingga dewasa dan gender. Cabai dan tomat dalam pangsa pasarnya tidak akan tergerus oleh zaman tergantung dengan bagaimana seorang Pemula Bisnis menjadi inovatif, kreatif dan risk taker (Sulastri, Wahab, and Varbi, 2017). Setiap orang dapat menjadi wirausaha, tergantung bagaimana niat dan menerapkan niat tersebut. Menjadi wirausaha tidak terbatas oleh umur, bahkan dengan teknologi yang ada saat ini menjadi wirausaha dapat dimulai dari usia dini. Secara sederhana, kinerja pemula bisnis dilihat dari tingkat kelangsungan hidup usaha, keuntungan berkelanjutan, produktivitas, kreatifitas, inovasi, kemampuan untuk merekrut tenaga kerja dan pengelolaan keuangan (Sulastri, 2014). Pada bagian ini memberi muatan bahwa pembelian bahan dalam jumlah banyak tidak hanya dapat dikonsumsi namun juga dapat dikembangkan menjadi usaha baru yang memberi peluang dalam masa era new normal dengan teknik hilirisasi produk seperti yang telah disebutkan di atas.

Adapun tujuan dari dilakukannya kegiatan ini adalah sebagai berikut: 1) memberikan pelatihan praktis membuat olahan makanan yang tahan dan tetap memiliki cita rasa yang tinggi untuk memotivasi kahlayak sasaran membeli bahan dalam jumlah yang lebih banyak dengan cara stockist untuk persediaan 2 sampai 4 minggu, sebagai acra untuk mengurangi intensitas ke pasar tradisional, 2) memotivasi khalayak sasaran untuk mengurangi intensitas ke pasar tradisional dalam masa pandemi dan era new normal untuk memimalisir terjadinya transmisi Covid-19 pada klaster pasar tradisional.

\section{STUDI PUSTAKA}

\subsection{Transmisi Klaster Pasar Tradisional bagi Penularan Covid-19}

Meskipun ada pembatasan mobilitas nasional untuk menghentikan penularan virus corona, pasar tradisional selalu menjadi tempat pemberhentian pertama untuk membeli kebutuhan sehari-hari, berkat harga yang terjangkau, kesempatan untuk tawar-menawar, dan kebiasan perilaku sosial yang menyenangkan untuk berbelanja di pasar tradisional. Namun sehubungan dengan peristiwa pandemi global Covid-19 pasar tradisonal menjadi klaster dalam memberi kontribusi yang berarti dalam transmisi Covid-19 dengan ninamika perkembangan yang sangat cepat. Sebagaimana ditunjukkan dari hasil penelitiannya, pada gambar 2. Pada Gambar 3 menunjukkan terjadinya transmisi antar manusia dalam social network yang terjadi di Korea Selatan, dari epicentrum 6 orang menyebar ke epicentrum berikutnya yang berdampak pada 
ribuan manusia terdampak Covid-19. Interaksi manusia secara langsung dalam jejaring sosial semakin mempercepat terjadinya penyebaran yang sulit terkendalikan, hal inilah sebagai dasar perlunya lockdown area atau di Indonesia dengan istilah Pembatasan Sosial Berskala Besar (PSBB).

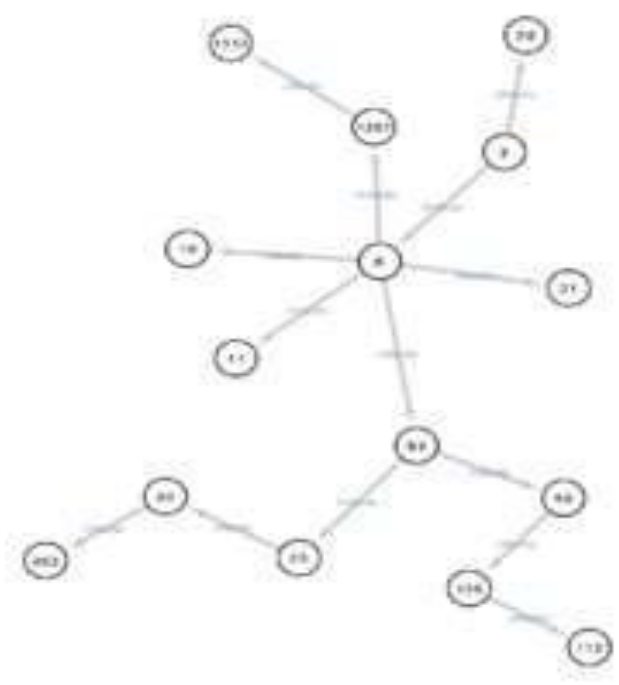

Gambar 2. Proses Transmisi Epicentrum pada Wet Market di Korea Selatan

Sumber: Youngjun, James (2020)

Hal yang sama ditunjukkan oleh Kenji Mizumoto, Katsushi Kagaya, Gerardo Chowell (2020) terjadinya transmisi dinamik Covid-19 antar manusia yang terjadi di pasar seafood Wuhan dari hari ke hari. Hasil penelitiannya menunjukkan adanya korelasi tranmsisi dari pasar ke manusia dan terjadinya penularan antar manusia ke manusia sebesar 2,27 artinya setiap satu orang rata-rata menularkan ke 2 orang, dan tingkat penularan dari pasar ke manusia berkisar antara 2-34 kali lipat atau lebih tinggi dari manusia ke manusia. Oleh karena itu pasar basah (wet market) memainkan peran penting dalam tranmisi penularan Covid-19.

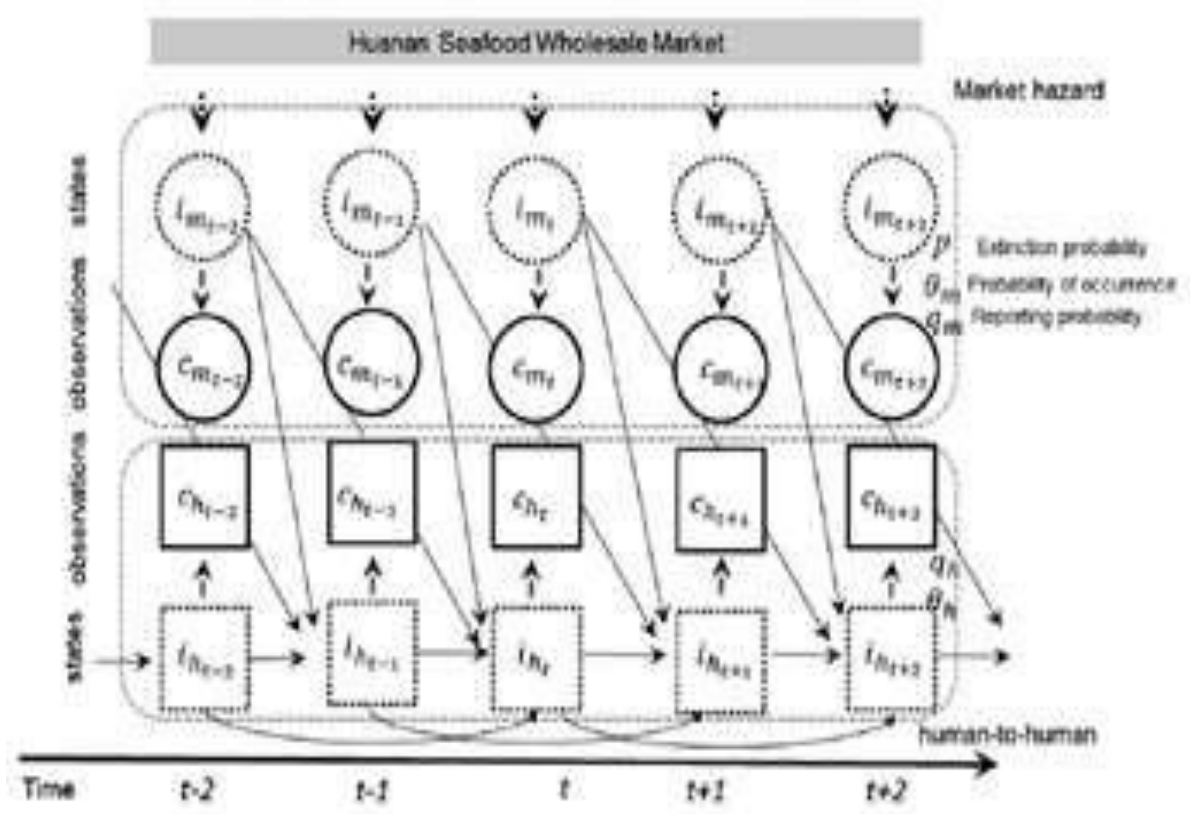

Gambar 3. Tranmisi Covid-19 di Pasar Tradisional Kota Wuhan China

Sumber: Kenji Mizumoto, Katsushi Kagaya, Gerardo Chowell (2020)

\subsection{Panic Buying dan Stockist}


Panic buying sebagai alah satu efek samping pada saat terjadi pandemi tertutama dengan adanya kebijakan pemerintah untuk melakukan lockdown atau shutdown beberapa pasar. Penimbunan makanan lazim terjadi selama pandemi Covid-19. perilaku menimbun, dapat dikelompokkan dengan cara rasional dan irasional. Dalam kondisi pandemi fenomena panic buying mungkin terjadi di masyarakat, yang dapat menyebabkan kelangkaan produk. Namun tidak dapat dipungkiri dapat terjadi penimbunan barang secara irasional dalam masa pandemic dengan perilaku panic buying. Dalam kaitan pandemic covid-19 H. Holly Wang, and Na Hao, (2020) menunjukkan bahwa perilaku panic buying secara psikolog sangat ditentukan oleh faktor suasana hati yang buruk. Sejalan dengan Samuel Lins, Sibele Aquino (2020) panic buying terjadi ketika perasaan negatif seperti ketakutan, panik, dan perasaan ketidakpastian memengaruhi perilaku, membuat orang membeli lebih banyak hal-hal dari biasanya. Namun beberapa penelitian perilaku panic buying hanya terjadi sementara Michael Keane (2021) menunjukkan bahwa panic buying terjadi meluas diberbagai negara sekitar bulan Maret dengan tingkat yang bervariasi dalam waktu dan tingkat keparahan. Rata-rata waku terjadinya panic buying antara 7 sampai 10 hari atau dalam jangka pendek (Michael Keane, 2021). Oleh karena itu, peran pemerintah perlu melakukan intervensi agar tidak terjadi panic buying, misalnya dengan intervensi berjangka waktu untuk mempengaruhi perilaku konsumen (Samuli Laato et al., 2020; Michael Keane, 2021).

Salah satu cara untuk mengatasi panic buying adalah dengan cara stockist, untuk menjamin ketersediaan bahan. Stockist dapat diartikan melakukan penyimpanan persediaan barang dalam jumlah tertentu secara dengan perencanaan untuk tujuan apakah dikonsumsi sendiri atau untuk didistribusikan ke pihak lain, namun dengan tidak cara menimbun barang dengan tujuan untuk menjual dengan harga yang lebih mahal. Untuk ini pihak retailer dan distributor harus bekerja sama menyediakan produk sesuai dengan kebutuhan. Proses stockist dilakukan baik untuk pedagang retailer dan konsumen sebagai satu mekanisme yang terintegrasi termasuk pada sektor agribisnis (Andrew Farrow, 2014). Situasi yang dipertimbangkan adalah di mana outlet penjualan menyimpan stok barang untuk dijual yang diisi ulang dengan pengiriman mingguan regular. Sistem stok yang tepat untuk digunakan dalam keadaan ini adalah kebijakan 'pesan-naik' tetapi masalahnya adalah mengatur tingkat pesanan-naik yang tepat untuk setiap item.

Untuk ini dibutuhkan peranan berbagai stakeholder, yang memiliki komitmen untuk mengatasi Covid-19, jangan sampai retailer mencari keuntungan dengan memanfaatkan kepanikan masyarakat. Untuk memudahkan stokist retailer dan distributor dapat memanfaatkan berbagai aplikasi yang banyak disediakan untuk direct order, seperti transaski on-line, untuk membatasi kontak phisik (Techsil, 2020).

\section{METODE}

Kegiatan pengabdian masyarakat ini dilaksanakan pada hari Sabtu, 21 November 2020. Kegiatan ini berlangsung dari pukul 14.00 WIB hingga 16.00 WIB. Pelaksanaan kegiatan dikuti oleh 28 Peserta yang terdiri dari masyarakat umum dan dosen. Kegiatan pengabdian masyarakat ini dilakukan melalui via Zoom Meeting. Metode yang digunakan dalam kegiatan ini adalah metode tutorial dan praktek. Metode ini dipilih untuk menyampaikan tahapan kegiatan secara praktis dapat diikuti oleh peserta. Penyampaian kegiatan dilakukan dengan pemutaran video yang dibuat berdasarkan kondisi riil.

Peserta melakukan pendaftaran melalui google form yang telah disebar sebelumnya. Pada saat melakukan registrasi, peserta diminta untuk mengisi pertanyaan mengenai kegiatan praktek pengolahan bahan makanan rumah tangga yang pernah dilakukan selama ini. Kegiatan ini dimulai dengan pemberian informasi mengenai literasi cara pengolahan bahan makanan awet dan tahan lama dengan penyimpanan sederhana dalam waktu 2 sampai 4 minggu. Selanjutnya, peserta juga diberikan informasi mengenai literasi bahwa pengolahan makanan dapat dikembangkan sebagai sumber pendapatan keluarga dan pengembangan kewirausahaan. Metode yang digunakan dalam kegiatan ini adalah metode tutorial dan praktek. Dilakukan pemutaran video praktek pengolahan bahan makan rumah tangga agar peserta dapat dengan mudah memahami materi yang diberikan. Pengamatan selama kegiatan dapat disimpulkan bahwa masih banyak peserta yang belum memahami pengolahan bahan makanan agar awet dan tahan lama. 
Setelah pemberian materi, dilakukan sesi diskusi dengan para peserta kegiatan dimana peserta dipersilahkan untuk memberikan pertanyaan ataupun tanggapan mereka mengenai pengolahan bahan makanan rumah tangga. Diakhir kegiatan, peserta diminta untuk mengisi pertanyaan mengenai tanggapan mereka terhadap pengolahan bahan makanan rumah tangga setelah mengikuti kegiatan pengabdian ini. Banyak dari peserta menanggapi bahwa setelah pemberian materi, mereka menyadari bahwa pengolahan bahan makanan rumah tangga merupakan kegiatan yang sangat bermanfaat dan inspiratif, karena memberikan informasi pengolahan makanan yang lebih sehat dan aman. Selain itu, peserta juga berpikir bahwa pengelolaan makanan dapat dikembangkan untuk menjadi peluang ide bisnis, sebagai sumber pendapatan keluarga dan pengembangan kewirausahaan.

Kegiatan pengabdian ini juga melakukan pembagian doorprize dan hasil pengolahan makanan kepada peserta. Doorprize akan langsung dikirimkan ke alamat rumah para peserta yang berhasil mendapatkan hadiah. Evaluasi akan dilakukan dengan cara membagikan kuesioner yang berhubungan dengan materi kegiatan setelah dilakukan kegiatan. Dalam evaluasi dipertanyakan apa yang merupakan kebutuhan, apa yang didapat, dan apa yang perlu diperbaiki dalam kegiatan ini.

\section{HASIL DAN PEMBAHASAN}

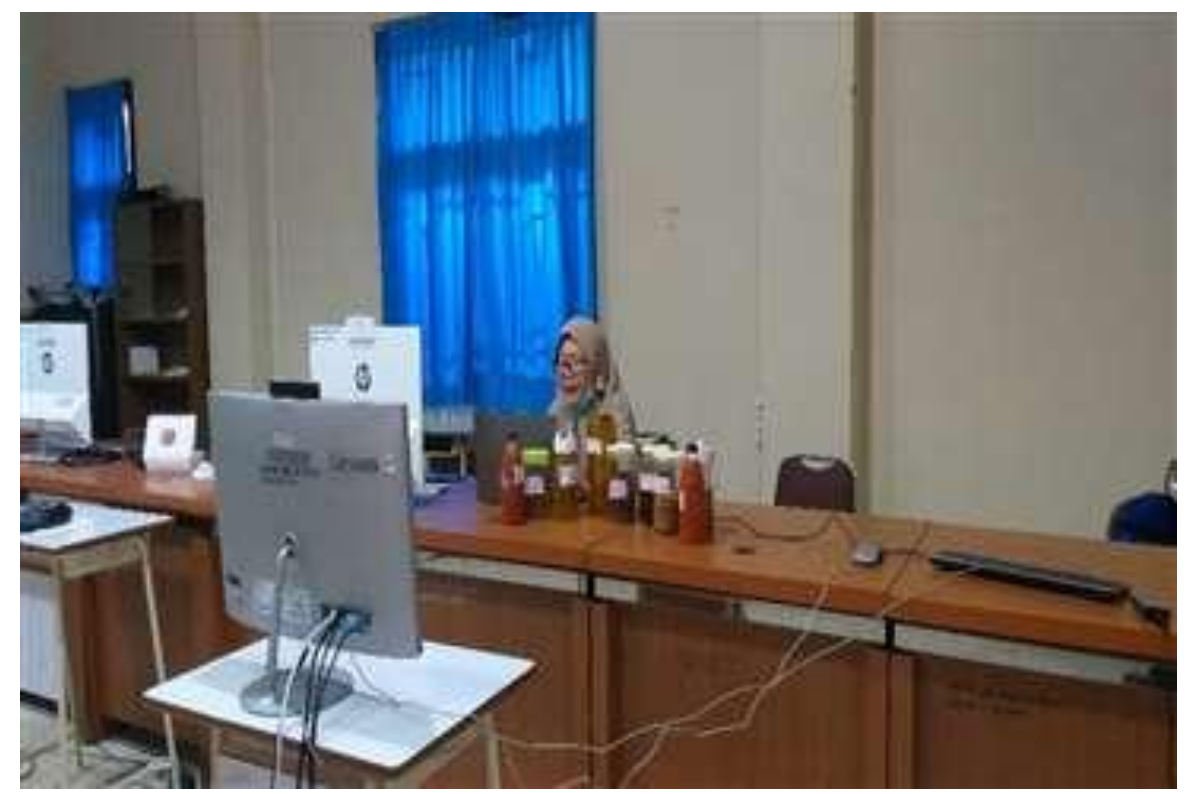

Gambar 4. Pemberian Materi Kegiatan Pengabdian Masyarakat

Klaster pasar tradisional menjadi salah satu pusat transmisi Covid 19 dari pasar ke manusia dan antar manusia (Yeongjun, James, 2020; Ivica Petrikova, Jennifer Cole, Andrew Farlow, 2020). Di Indonesia terdapat jumlah pasar tradisional atau rakyat pada 2019 mencapai 15.657 pasar pada tahun 2019. Jumlah tersebut bertambah 1.475 pasar atau 10.4 persen dibandingkan tahun sebelumnya. Data Badan Pusat Statistik (BPS). Sedangkan di Kota Palembang data terakhir 2014 tercatat memiliki jumlah pasar sebanyak 22 pasar, dengan 6.420 petak kios dan sekitar 7.346 jumlah pedagang (BPS Sumsel 2019). Pasar menjadi tempat menarik bagi para pembeli karena tersedianya berbagai kebutuhan sehari-hari yang relatif lengkap, harga yang relatif rendah, terjadi proses tawar menawar, dan harga umumnya lebih efisien karena banyak penjual dan pembeli sebagai ciri pasar sempurna dalam mekanisme pembentukan harga, dan perilaku sosial dengan kebiasaan yang tertarik dengan keramaian karena dapat pembelajaran dari pengalaman terhadap transfer pengetahuan, kemampuan membedakan poroduk dan memilih dengan cara menyenangkan untuk membeli bahan baku (Mohd Shazali Md, et al., 2016), disamping adanya persepsi bahwa pasar tradisional menyediakan sayur-sayur dan buah-buah segar (Abdullahi Auwal Gindi, at al., 2016). Hal ini sebagai alasan juga bahwa pasar basah (wet market) tidak terkalahkan 
oleh pasar modern. Beberapa peneliti menunjukkan bahwa pasar basah (wet market) di Asia belum terkalahkan dengan pasar modern (supermarket) Matthew Gorton, et al., (2011), Goldman, A., \& Vanhonacker, W. (2006). Hal ini menjadi tantangan pada saat terjadi pandemi untuk menentapkan strategi physical distancing, PSBB atau shutdown untuk memitigasi transmisi penularan Covid-19 dari klaster pasar tradisonal.

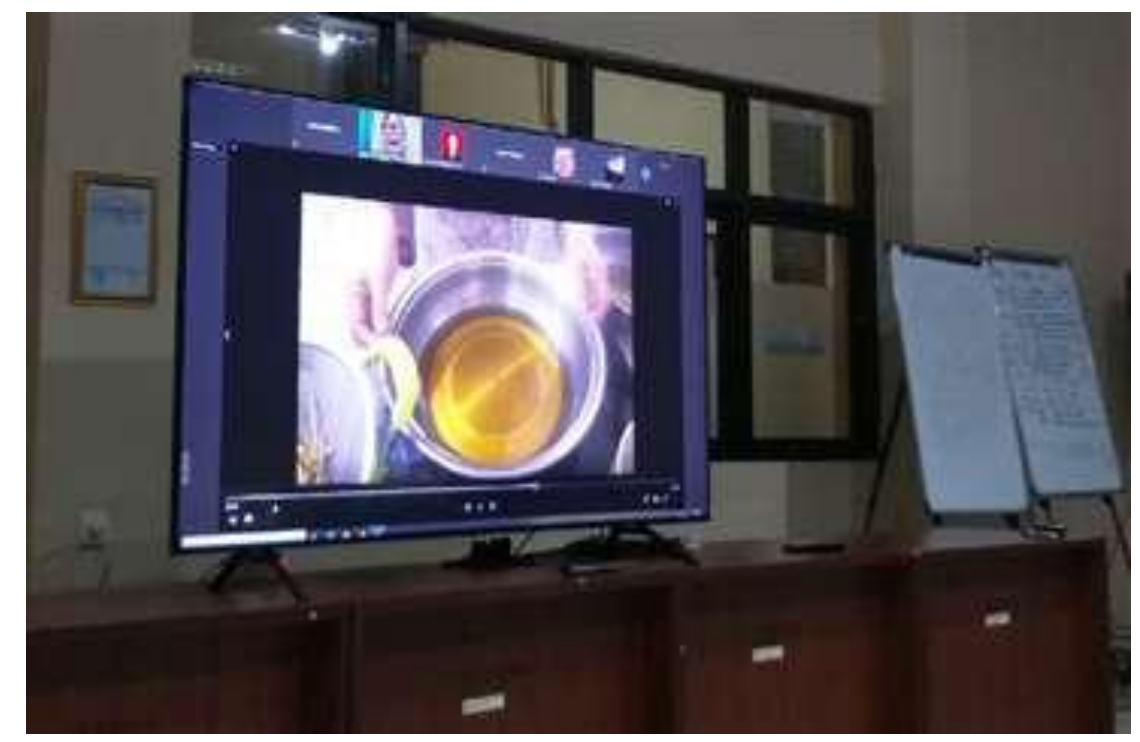

Gambar 5. Pemutaran Video Praktek Pengolahan Bahan Makanan Rumah Tangga

Tantangan ini dapat dimitigasi dengan tetap memperhatikan perilaku sosial masyarakat, melaksanakan protokol kesehatan, akan tetapi dengan cara mengurangi intensitas berbelanja di pasar melalui penyediaan bahan dalam jumlah yang lebih banyak untuk kebutuhan 2 sampai 4 minggu. Beberapa tulisan menunjukkan bahwa masa inkubasi Covid-19 berkisar dari 6 sampai 14 hari (Hansol Lee, et al., 2020; J.A. Quesada, et al., 2020). Selanjutnya untuk mempertahankan bahan makan yang telah dibeli, dapat dilakukan pengolahan bahan makanan sehingga tetap memiliki cita rasa yang tinggi dan tahan lama sampai waktu lebih 4 minggu. Mekanisme ini dilakukan dengan cara pelatihan dan tutorial pengolahan bahan makanan yang sering digunakan untuk dikonsumsi.

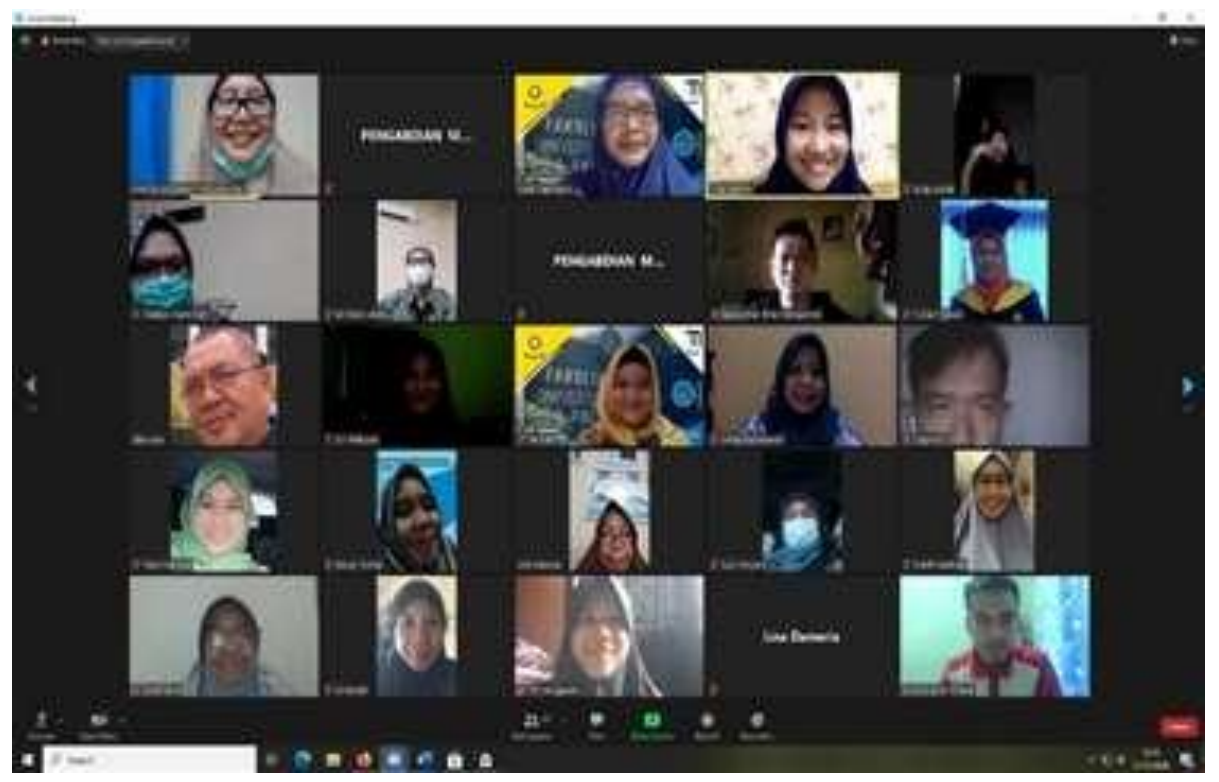

Gambar 6. Peserta Kegiatan Pengabdian Masyarakat

Kegiatan pengabdian masyarakat dalam bentuk tutorial dan praktek pengolahan makanan sebagai salah satu cara untuk mengurangi intensitas interaksi di pasar tradisional. Alasan ini 
dikarenakan beberapa kelompok masyarakat memperoleh pengetahuan bagaimana cara mengolah bahan makanan yang tahan lama dan memiliki cita rasa tinggi serta mudah untuk menyimpannya. Kegiatan pengabdian kepada masyarakat dalam bentuk tutorial, praktek langsung melalui pemutaran video yang ditunjukkan pada peserta melalui daring merupakan cara efektif dalam tranformasi pengetahuan pada saat kondisi pandemi.
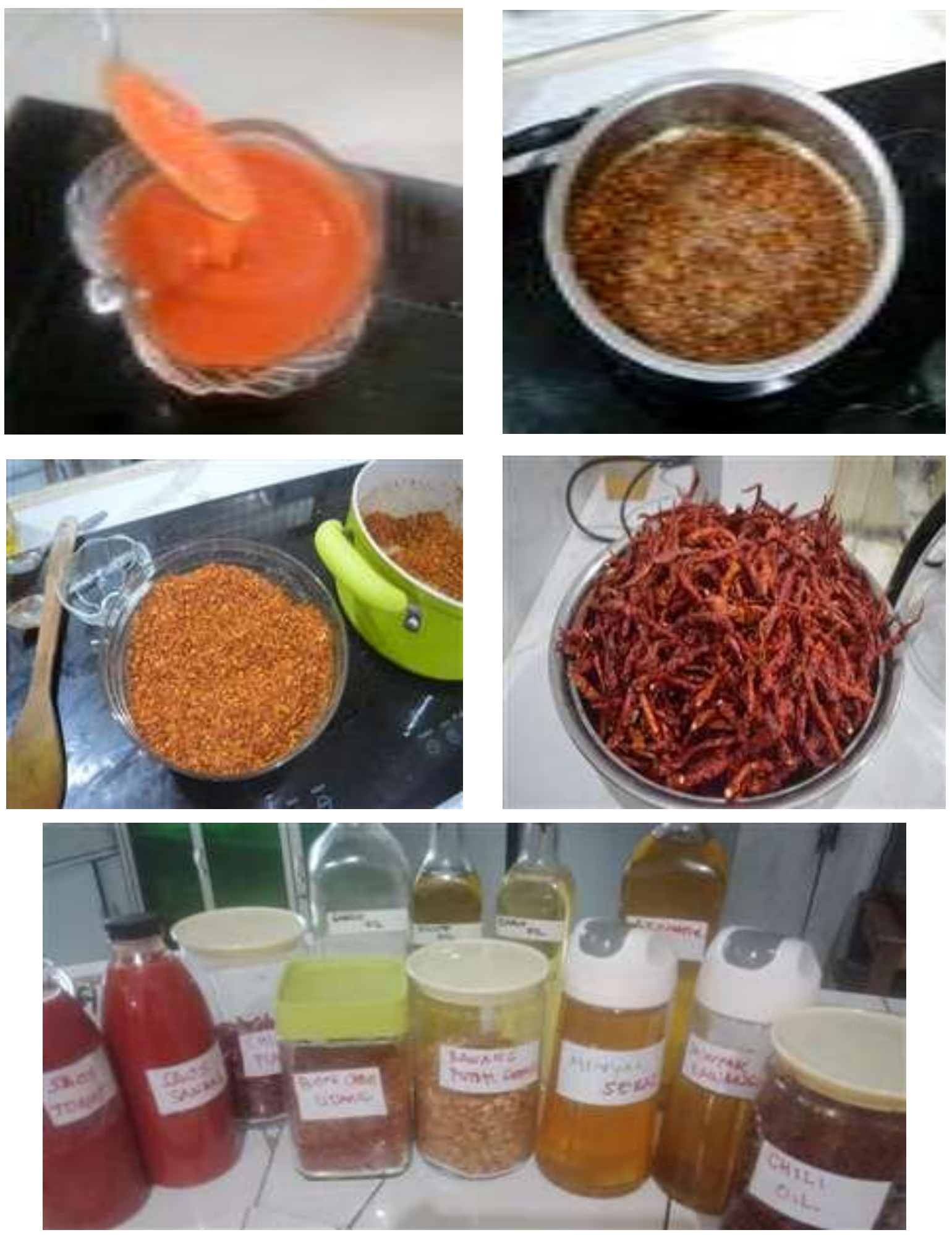

Gambar 7. Hasil Produk Pengolahan Makanan

Pemilihan bahan olahan adalah yang sering digunakan masyarakat sehari-hari seperti cabe, tomat, bawang dan minyak goreng. Minyak goreng sebagai bahan utama dalam proses 
pengawetan dan juga sinar matahari untuk proses pengeringan yang ditunjukkan dalam pemutaran video dan materi yang disampaikan. Beberapa tulisan menunjukkan bahwa teknik pengawetan sudah diterapkan sejak lama dalam kehidupan manusia. Salah satu cara pengawetan yang paling tua di antaranya adalah pengeringan, pengasinan, dan fermentasi serta disamping itu beberapa bahan alami yang dapat menjadi pengawet makanan adalah bawang putih, cuka, kayu manis dan lainnya. Bahan-bahan ini akan digunakan dalam kegiatan pengabdian pada kepada masyarakat yang menghasilkan beberapa produk seperti minyak cabe (chili oil), abon cabe, chili flake, dan sambal bangkok yang dikombinasi dengan bawang putih goring, minyak goreng sebagai tambahan bahan pengawet alami. Sedangkan produk yang lain adalah tip membuat bawang putih goreng renyah, garlic oil, aromatic oil, dengan aroma sereh, daun bawang dan sayuran lainnya. Diharapkan dengan literasi ini memotivasi peserta maupun penularan informasi kepada khalayak masyarakat agar dapat mengolah bahan baku tahan lama, sehingga tidak ada alasan untuk selalu sering ke pasar untuk mendapatkan bahan baku kebutuhan sehari hari. Dengan demikian akan terjadi paling tidak mengurangi intensitas ke pasar dalam rangka memitigasi transmisi Covid-19 dari klaster pasar tradisonal. Walaupun sampai saat ini belum ada penelitian bagaimana pengaruh literasi pengetahuan pengolahan bahan makanan sebagai faktor moderasi untuk mengurangi intensitas ke pasar tradisonal.

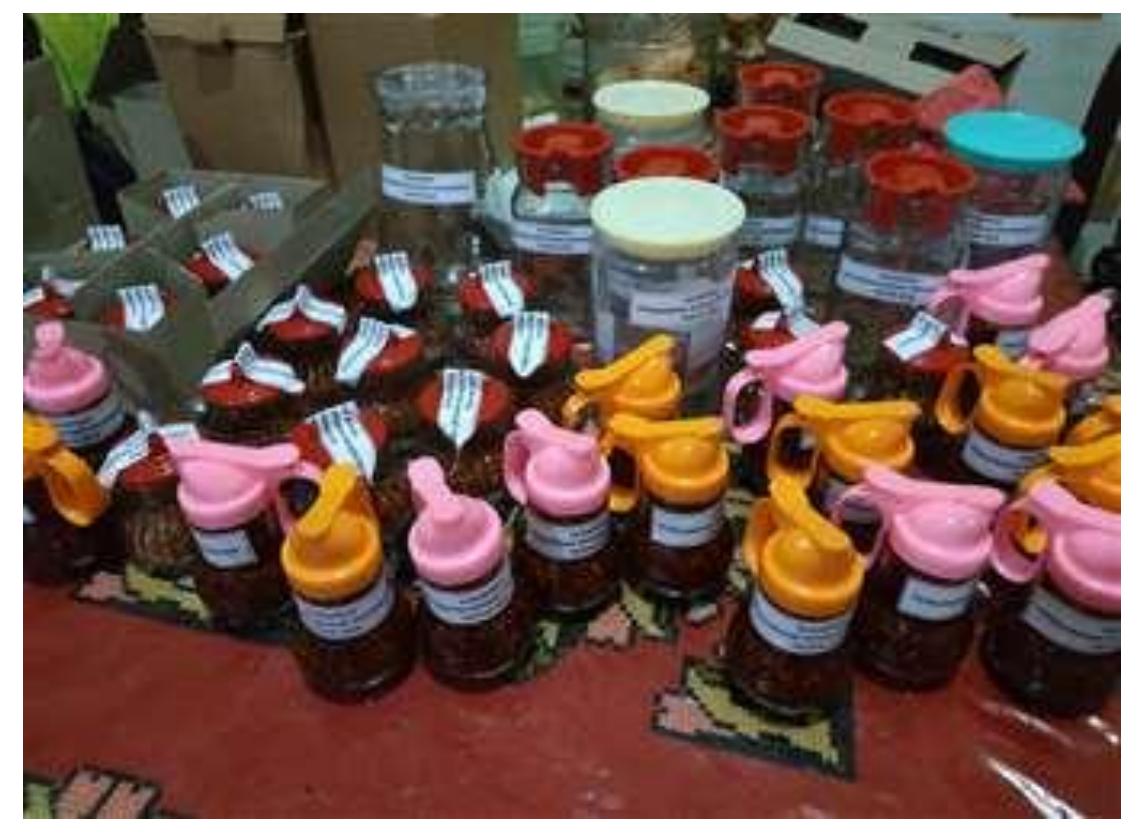

Gambar 8. Doorprize dibagikan ke peserta

Peserta rata-rata menyukai acara penyuluhan ini. Dengan adanya kegiatan pengabdian ini telah membantu peserta untuk menambah pengetahuan serta keterampilan mereka tentang cara pengolahan bahan makanan rumah tanggga. Materi yang telah disampaikan juga mudah dimengerti oleh peserta. Selain itu, peserta juga berpikir untuk menjadikan peluang ide bisnis, sebagai sumber pendapatan keluarga dan pengembangan kewirausahaan. Berikut ini rangkuman dokumentasi kegiatan pengabdian masyarakat.

\section{SIMPULAN}

Dari hasil pelaksanaan kegiatan di atas dapat disimpulkan beberapa hal, yaitu Kondisi pandemi Covid-19 sebagai peristiwa telah menimbulkan berbagai efek samping. Masyarakat harus mengurangi intensitas berbelanja di pasar melalui penyediaan bahan makanan rumah tangga dalam jumlah yang lebih banyak untuk kebutuhan 2 sampai dengan 4 minggu. Selanjutnya untuk mempertahankan bahan makan yang telah dibeli, dapat dilakukan pengolahan bahan makanan agar tetap memiliki cita rasa yang tinggi dan tahan lama sampai waktu lebih 4 minggu. Mekanisme yang dapat dilakukan adalah dengan cara pelatihan dan tutorial pengolahan bahan makanan 
rumah tangga yang sering digunakan untuk dikonsumsi.

Setelah diberikan informasi mengenai literasi cara pengolahan bahan makanan awet dan tahan lama dengan penyimpanan sederhana, tanggapan dan persepsi dari peserta berubah dimana mereka mulai paham mengenai cara pengolahan bahan makanan agar awet sampai waktu lebih 4 minggu. Sehingga tidak ada alasan untuk selalu sering ke pasar untuk mendapatkan bahan baku kebutuhan sehari hari selama pandemi Covid-19.

\section{UCAPAN TERIMA KASIH (ACKNOWLEDGMENTS)}

Kegiatan Pengabdian ini didanai oleh PNBP Universitas Sriwijaya. Terima kasih kepada panitia dan peserta kegiatan yang telah berpartisipasi dalam pelaksanaan kegiatan ini.

\section{REFERENSI}

Aguirre, A.A., Catherina, R., Frye, H., \& Shelley, L. (2020), Illicit Wildlife Trade, Wet Markets, and COVID-19: Preventing Future Pandemics. World Medical \& Health Policy, 12(3), 256-265. https://doi.org/10.1002/wmh3.348.

Arief, M., Fitriani, N., \& Subekti, S. (2014). Pengaruh Pemberian Probiotik Berbeda pada Pakan Komersial Terhadap Pertumbuhan dan Efisiensi Pakan Ikan Lele Sangkuriang (Clarias Sp.). Jurnal IImiah Perikanan dan Kelautan, 6(1), 49-53. http://dx.doi.org/10.20473/jipk.v6i1.11381.

Ariyani, N. I., \& Nurcahyono, O.H. (2014). Digitalisasi Pasar Tradisional: Perspektif Teori Perubahan Sosial. Jurnal Analisa Sosiologi, 3(1), 1-12. https://doi.org/10.20961/jas.v3i1.17442.

Badan Pusat Statistik (BPS). (2019). Provinsi Sumatera Selatan dalam Angka 2019. BPS Provinsi Sumatera Selatan.

Elsevier. (2020). Techsil buys UK adhesive stockist and distributor, Sealing Technology, 2020(4), 3. https://doi.org/10.1016/S1350-4789(20)30113-6.

Farrow, A., Risinamhodzi, K., Zingore, S., \& Delve, R.D. (2011). Spatialy targeting the distribution of agricultural input stockists in Malawi, Agricultural Systems. 104 (9),694-702. https://doi.org/10.1016/j.agsy.2011.07.003.

Gindi, A. A., Abdullah, A. M., Ismail, M. M., \& Nawi, N. M. (2016). Shopping Drivers of Generational Cohorts: A Comparison between Night Market and Wet Market Formats for Fresh Fruit and Vegetable Purchase in Malaysia. Australasian Marketing Journal, 24(2), 165-170. https://doi.org/10.1016/j.ausmj.2016.05.002.

Goldman, A., \& Vanhonacker, W. (2006). The food retail system in China: Strategic dilemmas and lessons for retail internationalization/modernization. Paper presented at the Globalizing Retail Conference, University of Surrey, Guildford, UK.

Gorton, M., Sauer, J., \& Supatpongkul, P. (2011). Wet markets, supermarkets and the "big middle" for food retailing in developing countries: Evidence from Thailand. World Development, 39(9), 1624-1637. https://doi.org/10.1016/j.worlddev.2011.02.005.

Jawad , A.J. (2020). Effectiveness of population density as natural social distancing in COVID-19 spreading, Ethics, Medicine and Public Health. 15(October), 1-15. https://doi.org/10.1016/j.jemep.2020.100556.

Keane, M., \& Neal, T. (2021). Consumer panic in the COVID-19 pandemic. Journal of Econometrics, 220(1), 86-105. https://doi.org/10.1016/j.jeconom.2020.07.045.

Kucharski, A.J., Klepac, P., Conlan, A.J.K., Kissler, S.M., Tang, M.L., Fry, H., Gog, J.R., \& Edmuns, W.J. (2020). Effectiveness of isolation, testing, contact tracing, and physical distancing on reducing transmission of SARS-CoV-2 in different settings: a mathematical modelling study. THE LANCET Infectious Diseases. 20(10), 1151-1160. https://doi.org/10.1016/S14733099(20)30457-6.

Laato, S., Islam, A.K.M.N., Farooq, A., \& Dhir, A. (2020). Unusual purchasing behavior during the early stages of the COVID-19 pandemic: The stimulus-organism-response approach. Journal of Retailing and Consumer Services, 57(November), 1-12. 
https://doi.org/10.1016/j.jretconser.2020.102224.

Lee, H., Kim, K. Choi, K., Hong S. ,Son H., \& Ryu, S. (2020). Incubation period of the coronavirus disease 2019 (COVID-19) in Busan, South Korea. Journal of Infection and Chemotherapy, 26(9), 1011-1013. https://doi.org/10.1016/j.jiac.2020.06.018.

Lins, S., \& Aquino, S. (2020). Development and initial psychometric properties of a panic buying scale during COVID-19 pandemic, Heliyon, 6(9), 1-6. https://doi.org/10.1016/j.heliyon.2020.e04746.

Lynteris, C., \& Fearnley, L. (2020). Why shutting down Chinese 'wet markets' could be a terrible mistake. The Conversation. https://theconversation.com/why-shutting-down-chinese-wetmarkets-could-be-a-terrible-mistake-130625

Mizumoto, K., Kagaya, K., \& Chowell, G. (2020). Effect of a wet market on coronavirus disease (COVID-19) transmission dynamics in China, 2019-2020. International Journal of Infectious Diseases, 97 (August), 96-101. https://doi.org/10.1016/j.ijid.2020.05.091.

Nauly, D. (2016). Fluktuasi dan Disparitas Harga Cabai di Indonesia. Jurnal Agrosains dan Teknologi, 1(1), 56-19.

Park, J. Y. (2020). Spatial visualization of cluster-specific Covid-19 transmission network in South Korea during the early epidemic phase. Medrxiv The Preprint Server For Health Sciences. https://doi.org/10.1101/2020.03.18.20038638.

Petrikova, I., Cole, J., \& Farlow, A. (2020). COVID-19, wet markets, and planetary health, The Lancet Planetary Health, 4(6), 213-214. https://doi.org/10.1016/S2542-5196(20)30122-4.

Pugersari, D., Syarief, A., \& Larasati, D. (2013). Eksperimen Pengembangan Produk Fungsional Bernilai Komersial Berbahan Baku Tempurung Kelapa Berusia Muda Dengan Teknik Pelunakan. ITB Journal of Visual Art and Design, 5(1), 74-91.

Quesada, J.A., López-Pineda, A., Gil-Guillén, V.F., Arriero-Marín, J.M., Gutiérrez, F., \& CarratalaMunuera, C. (2020). Incubation Period of COVID-19: ASystematic Review and Meta-Analysis. Revista Clinica Espanola (English Edition), 221(2), 109-117. https://dx.doi.org/10.1016\%2Fj.rceng.2020.08.002.

Sharif, M.S.M., Zahari, M.S.M., Nor, N.M., Muhammad, R. (2016). The Importance of Knowledge Transmission and its Relation towards the Malay Traditional Food Practice Continuity. Procedia - Social and Behavioral Sciences, 222 (June), 567-577. https://doi.org/10.1016/j.sbspro.2016.05.215.

Sulastri, Putri, Y.H., Muthia, F., \& Nadya.(2019). Peningkatan Produktivitas Pengolahan Buah Mangga Dengan Fasilitasi Peralatan Pengeringan Tenaga Matahari. In Semirata FEB BKS-PTN Barat 2019.

Sulastri, S., Wahab, Z., \& Varbi, V. (2017). Model konstruksi kognitif metaphora kewirausahaan: pendekatan konseptual. Jurnal Ekonomi, 22(2). doi:http://dx.doi.org/10.24912/je.v22i2.227

Sulastri. (2014). Science and Technological Development Model to Start Up Business on Student Enterpreneurship Program. Jurnal Pengabdian Sriwijaya, 2(2), 132-149. https://doi.org/10.37061/jps.v2i2.1607.

Wang, H. H., \& Hao, N.(2020). Panic buying? Food hoarding during the pandemic period with city lockdown. Journal of Integrative Agriculture, 19(12), 2916-2925.

https://doi.org/10.1016/S2095-3119(20)63448-7. 